\title{
Antioxidant Profile of Shilajatu (Asphaltum punjabinum): Impact of Drava/Media and Bhumi/Geography
}

\author{
Rohit Singh*, Shreshtha Kaushik, Pramod Yadav, Pradeep Kumar Prajapati
}

\section{Rohit Singh*, Shreshtha Kaushik, Pramod Yadav, Pradeep Kumar Prajapati}

Department of Rasa Shastra and Bhaishajya Kalpana, All India Institute of Ayurveda, Gautampuri, Sarita Vihar, Mathura Road, New Delhi-110076, Delhi, INDIA.

\section{Correspondence}

\section{Dr. Rohit Singh}

Department of Rasa Shastra and Bhaishajya Kalpana, All India Institute of Ayurveda, Gautampuri, Sarita Vihar, Mathura Road, New Delhi-110076, Delhi, INDIA.

Phone no: +91 8076584701

E-mail: rohit13july@gmail.com

\section{History}

- Submission Date: 15-05-2021;

- Review completed: 07-06-2021;

- Accepted Date: 12-07-2021.

DOI : 10.5530/fra.2021.1.4

Article Available online

http://www.antiox.org

\section{Copyright}

(C) 2021 Phcog.Net. This is an openaccess article distributed under the terms of the Creative Commons Attribution 4.0 International license.

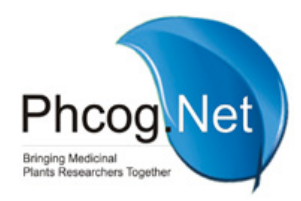

\begin{abstract}
Introduction: The superoxide radical $\left(\mathrm{O}_{2}-\right)$, hydroxyl radical $(\mathrm{OH})$ are generated in physiochemical pathways. All biological systems have innate antioxidant defence mechanisms but these mechanisms can be inefficient due to poor diet intake, pollution, stress and chemicals etc. Therefore, it is imperative to consume antioxidants to shield cells from destruction by free radicals. Shilajatu is such a drugs of prime importance that has been advocated in the management of various ailments ranging from Diabetes to Immunomodulation and Antioxidant. Materials and Methods: The antioxidant potential of Shuddha Shilajatu along with impact of geography and processing media on it, was determined by using DPPH i.e. 1,1-diphenyl2-picrylhydrazyl Free Radical Scavenging Assay. Test was performed at the wavelength of $517 \mathrm{~nm}$ using $1 \mathrm{~cm}$ optical path cuvette at room temperature. The ultraviolet spectrum of Shuddha Shilajatu and Ascorbic acid was performed by UV-Vis spectrophotometer at different concentrations. The experiment was carried out in triplicate. The result was compared with ascorbic acid as it was taken as standard control under the same conditions. The sample concentration at which initial absorbance of DPPH solution get lowered by $50 \%$ has been considered as the endpoint for evaluating the antioxidant potential. Results: It has been found that Shilajatu samples processed in Triphala kwatha have shown better antioxidant profile than water processed samples. Moreover, sample procured from Amritsar showed much better antioxidant activity in comparison to Shilajatu sample procured from Nepal. Conclusion: Processing media and geography significantly modulate the effect and activities of Shilajatu.

Key words: Antioxidants, DPPH, Free radicals, Oxidative stress, Shilajatu.
\end{abstract}

\section{INTRODUCTION}

Free radicals are ineluctably generated in biological systems as well as from exogenous sources. They are responsible to trigger off numerous degenerative disorders like mutations, cancer, cardiovascular diseases and ageing. ${ }^{1}$ A free radical is an unstable molecule that possesses an unpaired electron. This radical can become stable either by donating or accepting electron with biological molecules like lipids, proteins and DNA in the cells and leads to protein and DNA damage. ${ }^{2}$ Oxidative stress plays an important role in many diseases. The production of oxidative stress can be controlled by the antioxidant systems in living organisms. The oxygen radicals, such as superoxide radical $\left(\mathrm{O}_{2}-\right)$, hydroxyl radical $(\mathrm{OH})$ and non free radical species, such as singlet oxygen $\left(\mathrm{O}_{2}\right)$ and hydrogen peroxide $\left(\mathrm{H}_{2} \mathrm{O}_{2}\right)$, are generated in many redox processes of normal physiochemical path ways. ${ }^{3,4}$ These reactive oxygen species (ROS) along with oxidative stress leads to the various degenerative diseases. ${ }^{5-7}$ Therefore, antioxidants can be utilized to reverse the harmful and pathological action of free radicals. These antioxidants generally restore the normal physiological system by scavenging the free radicals.

Biological systems have their own intrinsic antioxidant defence mechanisms that eliminate damaged or injured molecules, but these protective mechanisms can be less effective due to poor diet intake, pollution, stress and chemicals etc. Therefore, it is essential to consume antioxidants to shield cells from destruction by free radicals. The antioxidants in use are either derived naturally from plants or synthetically. Synthetic antioxidants are not the preferred type of anti oxidants due to their higher probability of being carcinogenic. ${ }^{8}$ Therefore, latest researches in the field of free radical biology accentuate the use of antioxidants from natural origin and in view of this more and more antioxidants derived from natural origin or sources are being investigated.

Shilajatu is a blackish brown exudation found in the rocks at altitudes of 1000 to 5000 meters in Uttarakhand, Himachal Pradesh, Nepal, Pakistan, Afghanistan, Tajakistan, Russia etc. ${ }^{9}$ It is included in drugs of prime importance in Ayurveda and also in other traditional system of medicine. It has been advocated indigenously for treating various ailments ranging from Diabetes, Cardiac disorders etc. to Immunomodulation i.e. Rasayana Karma. ${ }^{10}$ 
In view of all these facts and need, the present study has been planned to evaluate antioxidant activity of Shuddha Shilajatu along with impact of geography and processing media on it, using 1,1-diphenyl-2-picrylhydrazyl (DPPH) Free Radical Scavenging Assay. The DPPH free radical is stable and has been widely approved as a tool for evaluating free radicalscavenging capacity of antioxidants..$^{11,12}$

\section{MATERIALS AND METHODS}

\section{Apparatus and Materials required}

UV-1800, UV Vis. Spectrophotometer (Shimadzu, Japan), 1,1-di-phenyl-2picryhydrazyl (DPPH, Sigma-Aldrich Co., Ltd., U.S) Shuddha Shilajatu of Nepal and Amritsar processed in Triphala kwatha and Water separately, Ascorbic acid standard (Sigma-Aldrich Co. Ltd., U.S, Purity $>98 \%$ ), Absolute Ethanol, Distilled water, Vortex, Analytical balance, Micro pipette, Culture tubes/Test tubes with cap, Test tube stand, Glass stirrer, Funnel, Conical flasks with stopper, Volumetric flasks.

\section{Samples}

Ashuddha Shilajatu samples were collected from Amritsar (supplied from Pakistan) and Nepal in the month of May, 2019. All samples were processed in Triphala Kwatha [Decoction of Phyllanthus emblica Linn., Terminalia chebula Retz. and Terminalia bellirica (Gaertn.) Roxb.] and Water as per the method mentioned in classical texts of Ayurveda ${ }^{13}$ and designated as ASW (Amritsar Shilajatu processed in Water), NSW (Nepal Shilajatu processed in Water), AST (Amritsar Shilajatu processed in Triphala kwatha) and NST (Nepal Shilajatu processed in Triphala kwatha)

\section{Preparation of DPPH solution}

DPPH (3.94 mg) was weighed on a chemical balance with a minimum weighing limit of $10 \mu \mathrm{g}$ or smaller. Thereafter, it was dissolved in $99.5 \%$ ethanol to obtain a constant volume by filling $50 \mathrm{ml}$ of a measuring flask or a measuring cylinder with a stopper $(0.1 \mathrm{mM} \mathrm{DPPH})$. It has been experimentally observed that the DPPH solution absorbance decreases with time up to approximately $1 \mathrm{hr}$ post preparation. Thereby, the solution was peserved in the dark for $2 \mathrm{hrs}$ until the stabilization of absorbance.

\section{Preparation of Blank sample solution}

Blank sample was prepared by adding distilled water $(1 \mathrm{ml})$ to the $1 \mathrm{ml}$ of above DPPH solution and mixed well with the help of vortex.

\section{Preparation of Standard sample solution}

$100 \mathrm{mg}$ of Ascorbic acid was dissolved in $100 \mathrm{ml}$ distilled water to prepare stock solution. Final standard solution was prepared by taking $2 \mathrm{ml}$ of stock solution and volume makeup was done to $5 \mathrm{ml}$. This solution of ascorbic acid added to the $1 \mathrm{ml} \mathrm{DPPH}$ solution (volume makeup to $2 \mathrm{ml}$ with distilled water) at various concentrations.

\section{Preparation of test drug sample solution}

Aqueous solution of Shuddha Shilajatu was added to $1 \mathrm{ml}$ of DPPH solution (volume makeup to $2 \mathrm{ml}$ with distilled water) at various concentrations.

\section{DPPH assay procedure}

Free radical scavenging potential of the Shilajatu extracts were tested by Blois ${ }^{14}$ method of free radical scavenging assay using 1,1-diphenyl2-picrylhydrazyl (DPPH). The reaction mixtures of all samples were thoroughly vortexed and kept in dark for $30 \mathrm{~min} .{ }^{15}$ Test was performed at the wavelength of $517 \mathrm{~nm}$ using $1 \mathrm{~cm}$ optical path cuvette at room temperature. The ultraviolet spectrum of Shuddha Shilajatu and
Ascorbic acid was performed by UV-Vis spectrophotometer (SHIMADZU, UV-1800) at different concentrations. The experiment was carried out in triplicate. The hydrogen atom donating capaability of the Shuddha Shilajatu extracts were evaluated by the decolourization of ethanol solution of DPPH. It produces violet/ purple colour in ethanol solution and diminishes to tints of yellow colour when there is presence of antioxidants. The result was compared with ascorbic acid as it was taken as standard control under the same conditions. The sample concentration that can reduce the initial absorbance of solution of $\mathrm{DPPH}$ by $50 \%$ has been considered as the endpoint for determining the antioxidant activity.

\section{Determination of Radical Scavenging Activity Percentage}

$\%$ DPPH Free radical scavenging activity $=\left(\mathrm{A}_{0}-\mathrm{A}_{1}\right) / \mathrm{A}_{0} \times 100$

Where, $\mathrm{A}_{0}$ denotes absorbance of the control/blank, and $\mathrm{A}_{1}$ signifies the absorbance of the extractives/standard. Then percentage of inhibition was plotted with respect to the concentration. The $\mathrm{IC}_{50}$ was calculated with the help of graph.

\section{$\mathrm{IC}_{50}$ Calculation}

Log dose inhibition curve was used to calculate the $\mathrm{IC}_{50}$ value of the sample i.e. concentration of sample needed to inhibit $50 \%$ of the DPPH free radical. Lower absorbance for the reaction mixture signifies higher free radical activity. ${ }^{16}$

\section{RESULTS}

The DPPH scavenging essay revealed potent antioxidant effect of Shuddha Shilajatu on free radicals. The percentage of antioxidant activity of Shilajatu samples processed in water and Triphala kwatha at different sample volume are depicted in Tables 1 and 2. Antioxidant activity percentage of ascorbic acid has been presented in Table 3. Comparative $\mathrm{IC}_{50}$ value of samples of Shilajatu processed in water and Triphala kwatha is calculated by plotting the graph (Figure 1 and 2) between DPPH inhibitory activity percentage and volume of sample taken. $\mathrm{IC}_{50}$ of ascorbic acid has been calculated through Figure 3. $\mathrm{IC}_{50}$ Calculation of various samples of Shuddha Shilajatu has been done as follows:

\section{$\mathrm{IC}_{50}$ Calculation for Amritsar Shilajatu processed in Water (ASW)}

$$
y=0.0237 x+35.212
$$

Here $\mathrm{Y}=50$ (as we have to calculate $50 \%$ DPPH activity).

$\mathrm{IC}_{50}$ value of $\mathrm{ASW}=623.97 \mu \mathrm{g} / \mathrm{ml}$

$\mathrm{IC}_{50}$ Calculation for Amritsar Shilajatu processed in Triphala kwatha (AST)

$$
y=0.5999 x+11.031
$$

Here $\mathrm{Y}=50$ (as we have to calculate $50 \% \mathrm{DPPH}$ activity). $\mathrm{IC}_{50}$ value of $\mathrm{AST}=64.96 \mu \mathrm{g} / \mathrm{ml}$

$\mathrm{IC}_{50}$ Calculation for Nepal Shilajatu processed in Water (NSW)

$$
y=0.0143 x+9.2157
$$

Here $\mathrm{Y}=50$ (as we have to calculate $50 \%$ DPPH activity).

$\mathrm{IC}_{50}$ value of $\mathrm{NSW}=2852.05 \mu \mathrm{g} / \mathrm{ml}$ 


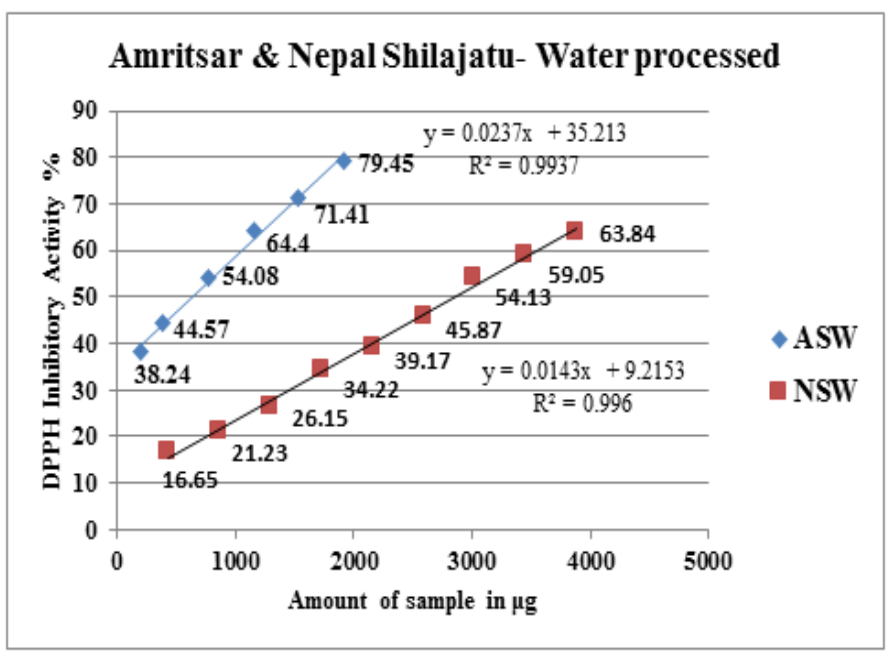

Figure 1: DPPH Inhibitory percentage of ASW \& NSW at different concentrations.

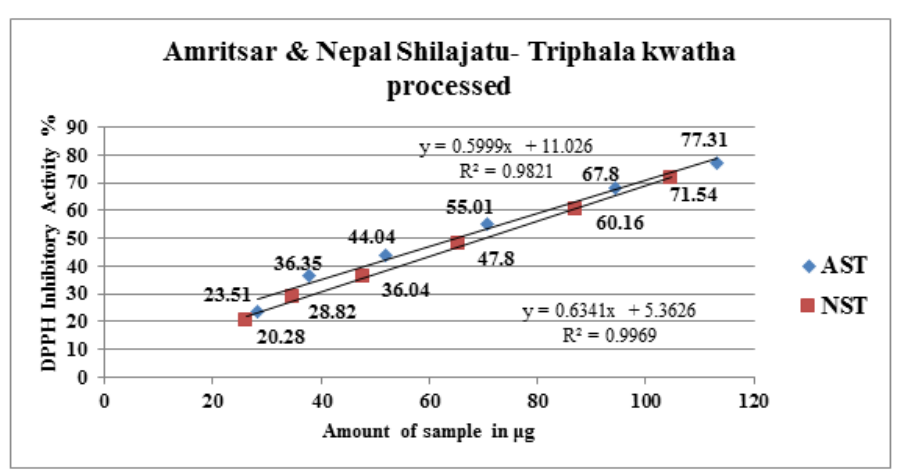

Figure 2: DPPH Inhibitory percentage of AST \& NST at different concentrations.

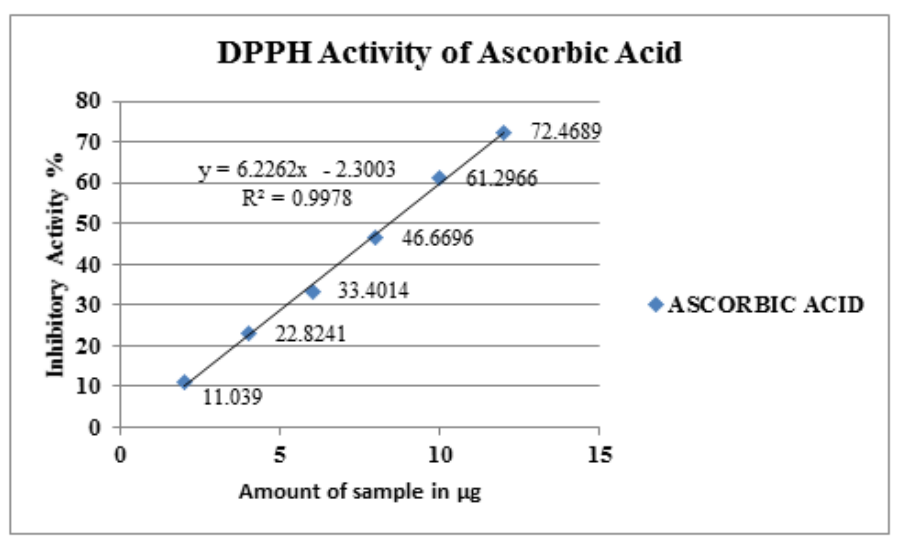

Figure 3: DPPH Inhibitory percentage of Ascorbic acid at different concentrations.

$\mathrm{IC}_{50}$ Calculation for Nepal Shilajatu processed in Triphala kwatha (NST)

$$
y=0.6342 x+5.3583
$$

Here $\mathrm{Y}=50$ (as we have to calculate $50 \%$ DPPH activity).

$\mathrm{IC}_{50}$ value of $\mathrm{NST}=70.39 \mu \mathrm{g} / \mathrm{ml}$

$\mathrm{IC}_{50}$ Calculation for Ascorbic Acid

$$
y=6.2262 x-2.3002
$$

Here $\mathrm{Y}=50$ (as we have to calculate $50 \%$ DPPH activity). $\mathrm{IC}_{50}$ value of $\mathrm{NST}=8.40 \mu \mathrm{g} / \mathrm{ml}$

\section{DISCUSSION}

In general "free radical scavenging activators" are known as "Antioxidant" that neutralizes free radicals being generated in the body and prevent

Table 1: DPPH scavenging activity of Amritsar and Nepal Shilajatu processed in Water.

\begin{tabular}{|cccccccccccccccc} 
Sample ID & ASW1 & ASW2 & ASW3 & ASW4 & ASW5 & ASW6 & NSW1 & NSW2 & NSW3 & NSW4 & NSW5 & NSW6 & NSW7 & NSW8 & NSW9 \\
\hline DPPH Solution $(\mathbf{m l})$ & $1 \mathrm{ml}$ & $1 \mathrm{ml}$ & $1 \mathrm{ml}$ & $1 \mathrm{ml}$ & $1 \mathrm{ml}$ & $1 \mathrm{ml}$ & $1 \mathrm{ml}$ & $1 \mathrm{ml}$ & $1 \mathrm{ml}$ & $1 \mathrm{ml}$ & $1 \mathrm{ml}$ & $1 \mathrm{ml}$ & $1 \mathrm{ml}$ & $1 \mathrm{ml}$ & $1 \mathrm{ml}$ \\
Volume of sample $(\mu \mathrm{l})$ & 10 & 20 & 40 & 60 & 80 & 100 & 20 & 40 & 60 & 80 & 100 & 120 & 140 & 160 & 180 \\
Amount of sample $(\mu \mathrm{g})$ & 192 & 384 & 768 & 1152 & 1536 & 1920 & 432 & 864 & 1296 & 1728 & 2160 & 2592 & 3024 & 3456 & 3888 \\
Optical density (0.D) & 0.7559 & 0.6785 & 0.5621 & 0.4358 & 0.3499 & 0.2515 & 1.0202 & 0.9642 & 0.9039 & 0.8051 & 0.7445 & 0.6625 & 0.5615 & 0.5012 & 0.4426 \\
DPPH activity (\%) & 38.24 & 44.57 & 54.08 & 64.40 & 71.41 & 79.45 & 16.65 & 21.23 & 26.15 & 34.22 & 39.17 & 45.87 & 54.13 & 59.05 & 63.84 \\
\hline
\end{tabular}

ASW Concentration: $19 \mu \mathrm{g} / \mathrm{ml}$, NSW Concentration: $21.6 \mu \mathrm{g} / \mathrm{ml}$; Note: Final volume makeup to $2 \mathrm{ml}$ with distilled water.

Table 2: DPPH scavenging activity of Amritsar and Nepal Shilajatu processed in Triphala kwatha

\begin{tabular}{|cccccccccccccc} 
Sample ID & AST1 & AST2 & AST3 & AST4 & AST5 & AST6 & NST1 & NST2 & NST3 & NST4 & NST5 & NST6 \\
\hline DPPH Solution $(\mathbf{m l})$ & $1 \mathrm{ml}$ & $1 \mathrm{ml}$ & $1 \mathrm{ml}$ & $1 \mathrm{ml}$ & $1 \mathrm{ml}$ & $1 \mathrm{ml}$ & $1 \mathrm{ml}$ & $1 \mathrm{ml}$ & $1 \mathrm{ml}$ & $1 \mathrm{ml}$ & $1 \mathrm{ml}$ & $1 \mathrm{ml}$ \\
Volume of sample $(\mu \mathbf{l})$ & 60 & 80 & 110 & 150 & 200 & 240 & 60 & 80 & 110 & 150 & 200 & 240 & \\
Amount of sample $(\mu \mathrm{g})$ & 28.32 & 37.76 & 51.92 & 70.80 & 94.40 & 113.28 & 26.1864 & 34.9152 & 48.0084 & 65.466 & 87.288 & 104.7456 \\
Optical density (0.D) & 0.9362 & 0.7790 & 0.6849 & 0.5506 & 0.3941 & 0.2777 & 0.9758 & 0.8712 & 0.7829 & 0.6389 & 0.4876 & 0.3484 \\
DPPH activity (\%) & 23.51 & 36.35 & 44.04 & 55.01 & 67.80 & 77.31 & 20.28 & 28.82 & 36.04 & 47.80 & 60.16 & 71.54 \\
\hline
\end{tabular}

AST Concentration: $0.472 \mu \mathrm{g} / \mathrm{ml}$, NST Concentration: $0.436 \mu \mathrm{g} / \mathrm{ml}$; Note: Final volume makeup to $2 \mathrm{ml}$ with distilled water. 
Table 3: DPPH scavenging activity of Ascorbic Acid

$\begin{array}{cccccccc}\text { Sample ID } & \text { A1 } & \text { A2 } & \text { A3 } & \text { A4 } & \text { A5 } \\ \text { DPPH Solution }(\mathbf{m l}) & 1 \mathrm{ml} & 1 \mathrm{ml} & 1 \mathrm{ml} & 1 \mathrm{ml} & 1 \mathrm{ml} & 25 \\ \text { Volume of sample }(\boldsymbol{\mu l}) & 05 & 10 & 15 & 20 & 30 & 10 \\ \text { Amount of sample }(\boldsymbol{\mu g}) & 02 & 04 & 06 & 08 & 0.4358 \\ \text { Optical density (0.D) } & 1.0017 & 0.8690 & 0.7499 & 0.6005 & 0.3100 \\ \text { DPPH activity (\%) } & 11.0390 & 22.8241 & 33.4014 & 46.6696 & 61.2966\end{array}$

Ascorbic acid concentration: $0.4 \mu \mathrm{g} / \mathrm{ml}$; Note: Final volume makeup to $2 \mathrm{ml}$ with distilled water.

damage to the cell proteins, lipids and carbohydrates. ${ }^{17}$ Harmful free radicals play a crucial part in immune system dysfunction, which is responsible for various diseases like cancer, cardiovascular diseases, arthritis, ulcerative colitis, asthma and allergy etc. ${ }^{18,19}$ To eliminate generated damaged molecules, all biological systems consists integrated antioxidant defence mechanisms, but sometimes these mechanisms fell short to combat free radicals due to poor diet intake, pollution, stress and chemicals etc. Therefore, consumption of antioxidants is vital to protect cells from free radical damage. Their effect on systems biology may be exerted by different mechanisms like donating electron, metal ion chelation, co-antioxidants and by gene expression regulation. ${ }^{20}$ Several methods have been propounded for evaluating the anti-oxidative activity, such as 1,1-diphenyl-2-picryl hydrazyl (DPPH) method, 2,2'-azinobis- (3-ethylbenzo thiazolin-6-sulfonic acid), diammonium salt (ABTS) method, Ferric Reducing Antioxidant Power (FRAP) method and so on..$^{21-24}$

\section{The adopted model in the study has been used due to following rationale:}

- It is considered a valid accurate, easy and economic method to evaluate free radical scavenging activity of antioxidants.

- It is easy to perform and applies to evaluate the overall antioxidant capacity. ${ }^{25}$

- It has been efficiently and effectively used to investigatae antioxidant properties of variety of samples like wheat grain, vegetables, herbs etc. and can be performed using various solvent media including ethanol, aqueous, acetone, methanol, alcohol and benzene. ${ }^{26,27}$

An antioxidant is a stable enough molecule which can donate an electron to a free radical and stabilize or neutralize it, thus diminishing its potential to damage. These antioxidants by the virtue of their free radical scavenging property decelerate or inhibit cellular damage. ${ }^{28}$ In the present study, Shuddha shilajatu (processed in water and Triphala kwatha) have exhibited significant DPPH Scavenging activity by the virtue of donating a electron or hydrogen atom to the respective hydrazine ${ }^{29}$ of DPPH. Further, electron of nitrogen atom in DPPH got reduced and resulted in the reduced form with the loss of initial violet colour to yellow colour. Shilajatu sample procured from Amritsar and processed in water showed much better antioxidant activity $\left(\mathrm{IC}_{50}=623.97 \mu \mathrm{g} / \mathrm{ml}\right)$ in comparison to Shilajatu sample procured from Nepal and processed in water $\left(\mathrm{IC}_{50}=\right.$ $2852.05 \mu \mathrm{g} / \mathrm{ml}$ ). Similarly, Shilajatu sample procured from Amritsar and processed in Triphala kwatha showed slightly better antioxidant activity $\left(\mathrm{IC}_{50}=64.96 \mu \mathrm{g} / \mathrm{ml}\right)$ in comparison to Shilajatu sample procured from Nepal and processed in Triphala Kwatha $\left(7 \mathrm{IC}_{50}=0.39 \mu \mathrm{g} / \mathrm{ml}\right)$. These finding proffers strong evidence pertaining to effect of geography on the properties of Shilajatu. This is probably because of variation in quantum of various metals, minerals and herbal compound present in flora of a particular geographical region.

Present study revealed that processing media significantly modulate the effect and activities of Shilajatu as samples processed in Triphala kwatha have shown better antioxidant profile $\left(\mathrm{IC}_{50}=64.96\right.$ and $70.39 \mu \mathrm{g} / \mathrm{ml}$ ) than water processed sample of Shilajatu $\left(\mathrm{IC}_{50}=623.97\right.$ and $\left.2852.05 \mu \mathrm{g} / \mathrm{ml}\right)$. It is owing to the fact that Triphala is well reported and known for its antioxidant activitie. ${ }^{30}$ Therefore, findings provide evidence to the fact that Shuddha Shilajatu has properties of a potent antioxidant.

\section{Other anticipated pathways contributing to Antioxidant properties of Shilajatu}

- Studies have reported that Shilajatu significantly increases the SOD (Superoxide dismutases) and Catalase activity. ${ }^{31}$ SODs are a group of metalloenzymes that are found in all kingdoms of life. SODs act as the front line of defence against ROS mediated injury. It acts as a good therapeutic agent against reactive oxygen species-mediated diseases. ${ }^{32}$ Catalase is an enzyme found in animals, plants and bacteria. It catalyzes the decomposition of hydrogen peroxide is decomposed to to water and oxygen by its catalysing action. ${ }^{33}$ It protects the cell from oxidative damage caused by ROS. Millions of hydrogen peroxide molecules can be disintrgrated to water and oxygen by just one molecule of catalase each second. ${ }^{34}$

- Shilajatu can potentially control oxidative stress, by reducing the Malondialdehyde (MDA) levels in body. ${ }^{35,36}$ MDA is an endogenous genotoxic product of enzymatic and oxygen radical-induced lipid peroxidation. ${ }^{37}$ It contributes significantly in DNA damage and mutation which is produced endogenously through prostaglandin biosynthesis and lipid peroxidation. ${ }^{38}$

\section{CONCLUSION}

On account of the outcomes of present study, it can be inferred that Shuddha Shilajatu is a cogent antioxidant and can be useful in preventing the oxidative stress in the body. Free radicals and oxidative stress are reported to be one among the major causes of various diseases like Diabetes, premature ageing, Alzheimer's disease, neuro-degenerative disorders etc. Thereby, Shuddha Shilajatu may prove beneficial and effective in the treatment of numerous disorders. Furthermore, impact of geographical distribution and processing media is also observed to be significant. Shilajatu procured from Amritsar exhibited better antioxidant activity than sample procured from Nepal. In parallel, Shilajatu processed in Triphala kwatha has shown superior antioxidant properties over sample processed in water. In nutshell, Shuddha Shilajatu is a powerful antioxidant and processing media can be selected appertaining to nature of disease and purpose.

\section{ACKNOWLEDGEMENT}

We thank Dr. Sanjay Singh, Principal, Siddhartha Institute of Pharmacy, Dehradun, India for providing infrastructure facilities to carry out the research work. Dr. Ritu, Dr. Pankaj, Dr, Rajesh Singh and Ms. Himani are also acknowledged for rendering their expertise throughout the assay. We would also like to thank All India Institute of Ayurveda for providing fund to carry out the work under MD Dissertation. 


\section{CONFLICT OF INTEREST}

The authors declare no conflict of interest.

\section{ABBREVIATIONS}

ABTS: 2,2'-azino-bis(3-ethylbenzothiazoline-6-sulfonic acid); AST: Amritsar Shilajatu processed in Triphala kwatha; ASW: Amritsar Shilajatu processed in Water; DNA: Deoxyribonucleic acid; DPPH: 1,1-diphenyl2-picrylhydrazyl; FRAP: Ferric Reducing Antioxidant Power; $\mathbf{H}_{2} \mathbf{O}_{2}$ : Hydroxyl radical; $\mathrm{IC}_{50}$ : Half maximal Inhibitory Concentration; MDA: Malondialdehyde; NST: Nepal Shilajatu processed in Triphala kwatha, NSW: Nepal Shilajatu processed in Water; $\mathbf{O}_{2}-:$ Superoxide radical; $\mathbf{O H}$ : Hydrogen Peroxide; ROS: Reactive Oxygen Species; SOD: Superoxide dismutases.

\section{REFERENCES}

1. Singh S, Singh RP. In vitro methods of assay of antioxidants: An overview. Food Rev Int. 2008; 24(4): 392-415

2. Gilgun-SherkiY, Rosenbaum Z, Melamed E, Offen D. Antioxidant therapy in acute central nervous system injury: current state. Pharmacol Rev. 2002;54:271-284.

3. Martin I, Grotewiel MS. Oxidative damage and age-related functional declines. Mech Ageing Dev. 200;127(5): 411-423.

4. Kataki MS, Ahmed MZ, Awasthi D, Tomar B, Mehra P,Yadav RS. In vitro antioxidant profile of Wedelia calandulaceae leaves. Pharmacologia. 2012;3(3):75-83.

5. Chandan BK, Saxena AK, Shukla S, Sharma N, Gupta DK, Singh K. Hepatoprotective activity of Woodfordia fruticosa Kurz flowers against carbon tetrachloride induced hepatotoxicity. J Ethnopharmacol. 2008;119(2):218-224.

6. Klaunig JE, Wang Z, Pu X, Zhou S. Oxidative stress and oxidative damage in chemical carcinogenesis. Toxicol Appl Pharmacol. 2011; 254(2): 86-99.

7. Radak Z, Zhao Z, Goto S, Koltai E. Age-associated neuro degeneration and oxidative damage to lipids, proteins and DNA. Mol Aspects Med. 2011; 32(4-6): 305-315

8. Kataki MS, Ahmed MZ, Awasthi D, Tomar B, Mehra P,Yadav RS. In vitro antioxidant profile of Wedelia calandulaceae leaves. Pharmacologia. 2012; 3(3): 75-83.

9. Kong YC, Butt PPH, Cheng KH, Cheng KF, Camble RC, Malla SB. Chemical studies on a Napalese panacea; Shilajit. Int J Crude Drug Res. 1987; 25: 179-187.

10. Ghosal S. Chemistry of Shilajit: an immunomodulatory Ayurvedic rasayan. Pure Appl Chem. 1990; 62: 1285-1288.

11. Fenglin $H$, Ruili $L, B a o H$, Liang $M$. Free radical scavenging activity of extracts prepared from fresh leaves of selected Chinese medicinal plants. Fitoterapia. 2005; 75(1): 14-23

12. Oyaizu M. Studies on product of browning reaction prepared from glucose amine. JPN J Nutr. 1986; 44(6): 307-315.

13. Vagbhatta, Rasa Ratna Samucchaya, Dattatreya kulkarni, Vigyan bodhini Hindi commentary, Meherchand Laxmandas publications, New Delhi. 2017; 5/172, $173,126$.

14. Blois MS. Antioxidant determinations by the use of a stable free radical. Nature. 1958; 181: 1199-1200.

15. Kim JK, Noh JH, Lee S, Choi JS, Suh H, Chung HY, Song YO, Choi WC. The first total synthesis of 2, 3, 6-tribromo-4, 5 dihydroxybenzyl methyl ether (TDB) and its antioxidant activity. Bull Korean Chem Soc. 2002; 23(5): 661-662.

16. Koleva II, Van BeekTA, Linssen JP, Groot AD, Evstatieva LN. Screening of plant extracts for antioxidant activity: a comparative study on three testing methods.
Phytochem Anal. 2002; 13(1): 8-17.

17. Joe E. Swanson: Antioxidant Nutrients, Cornell Nutrition Expert Overview. 1999; 2.

18. Shanthakumari P. Modulation of oxidative stress parameters by treatment with piper betle leaf in streptozotocin induced Diabetic rats. Ind J. Pharmc. 2003; 35: 373-378.

19. Patwardhan B, Kalbag D, Patki PS, Nagsampagi BA. Search of immunomodulatory agents: a review. Indian drugs. 1990; 28(2): 56-63.

20. Krinsky NI. Mechanism of action of biological antioxidants. Proc Soc Exp Biol Med. 1992; 200: 248-254.

21. Abderrahim F, Arribas SM, Gonzalez MC, Condezo-Hoyos L. Rapid high-throughput assay to assess scavenging capacity index using DPPH. Food Chem. 2013; 141:788-94.

22. Durmaz G. Freeze-dried ABTS+ method: a ready-to-use radical powder to assess antioxidant capacity of vegetable oils. Food Chem. 2012;133:1658-63.

23. 23. Martins AC, Bukman L, Vargas AMM, Érica O Barizao, Moraes JCG, Visentainer JV. The antioxidant activity of teas measured by the FRAP method adapted to the FIA system: optimising the conditions using the response surface methodology. Food Chem. 2013;138:574-580.

24. Merola N, Alonso FJG, Ros G, Castón MJP. Antioxidant activity comparison between (6s)-5-methyltetrahydrofolic acid calcium salt and the related racemate form. Food Chem,. 2013; 136: 984-988. 6-573.

25. Prakash A. Antioxidant activity. Med Lab Anal Prog. 2001; 19(2): 1-6.

26. Yu LL. Free radical scavenging properties of conjugated linoleic acids. J Agric Food Chem. 2001; 49: 3452-3456

27. Parry J, Su L, Luther M, Zhou KQ, Yurawecz MP, Whittaker P, Yu LL. Fatty acid composition and antioxidant properties of coldpressed marionberry, boysenberry, red raspberry, and blueberry seed oils. J Agric Food Chem. 2005; 53: 566-573.

28. Halliwell B. How to characterize an antioxidant- An update. Biochem Soc Symp 1995; 6: 73-101.

29. Contreras-Guzman ES, Strong FC. Determination of tocopherols (Vitamin E) by reduction of cupric ion. J Assoc Off Anal Chem. 65: 1215-1222.

30. Vani T, Rajani M, Sarkar S, Shishoo CJ. Antioxidant properties of the ayurvedic formulation triphala and its constituents. Int J Pharmacog. 1997; 35(5): 313-317.

31. Surapaneni DK, Adapa SR, Preeti K, Teja GR, Veeraragavan M, Krishnamurthy S. Shilajit attenuates behavioral symptoms of chronic fatigue syndrome by modulating the hypothalamic-pituitary-adrenal axis and mitochondrial bioenergetics in rats. J Ethnopharmacol. 2012; 143(1): 91-99.

32. Younus $\mathrm{H}$. Therapeutic potentials of superoxide dismutase. Int $\mathrm{J}$ Health Sci. 2018;12(3):88

33. Chelikani P, Fita I, Loewen PC. Diversity of structures and properties among catalases. Cell Mol Life Sci. 2004;61(2):192-208.

34. Goodsell DS. Catalase: Molecule of the Month. RCSB Protein Data Bank. 2004

35. Biswas TK, Pandit S, Mondal S, Biswas SK, Jana U, Ghosh T, et al. Clinical evaluation of spermatogenic activity of processed Shilajit in oligospermia. Andrologia. 2010; 42(1): 48-56

36. Gomez E, Irvine DS, Aitken RJ. Evaluation of a spectrophotometric assay for the measurement of malondialdehyde and 4-hydroxyalkenals in human spermatozoa: relationships with semen quality and sperm function. Int J Androl. 1998; 21(2): 81-94

37. Niedernhofer LJ, Daniels JS, Rouzer CA, Greene RE, Marnett LJ. Malondialdehyde, a product of lipid peroxidation is mutagenic in human cells. J Biol Chem. 2003;278(33):31426-33

38. Esterbauer H. Cytotoxicity and genotoxicity of lipid-oxidation products. Am J Clin Nutr. 1993; 57(5): 779-786.

Cite this article: Singh R, Kaushik S, Yadav P, Prajapati PK. Antioxidant Profile of Shilajatu (Asphaltum punjabinum): Impact of Drava/ Media and Bhumi/Geography. Free Radicals and Antioxidants. 2021;11(1):19-23. 